\title{
UMA SABEDORIA NO DESESPERO. HÁ QUE GRITAR AOS OUVIDOS DA APARENTE SURDEZ: SOMOS TODAS CAROLINA!
}

\section{Resumo}

O objetivo neste artigo é retomar a poesia transformadora como inspiração e negação frente à realidade enfrentada por mulheres negras e periféricas. Para tal intento, esquadrinharemos o trabalho de Carolina de Jesus, escritora negra que trabalhou como catadora de lixo no Brasil. Nosso ${ }^{2}$ propósito é evocar esta voz silenciada que gritava. A metodologia é a sintaxe sociológica de algumas obras de Carolina, objetivando resgatar, para aqueles que desconhecem, as violências que permeiam o existir desta voz que segue marginalizada. Afirmamos que Carolina não foi uma coletora, foi, sim, uma revolucionária que merece ser descoberta!

Palavras-chave: Memória, Favela, Mulheres, Negras, Poesia

\section{Abstract}

Wisdom in despair. Yelling at the ears of the apparent deafness: We are all Carolina! The aim in this paper is to present the transforming poetry as a form of inspiration and denial for black and peripheral women. For this purpose, we will research Carolina Maria de Jesus works, a black poet who worked as a garbage collector in Brazil. Our aim is to evoke her silenced voice as it was silenced in unawareness. Using the sociological syntax of some of Carolina's works as a methodological resource, we aim to revive the violence that permeated her existence as her voice remains marginalized. We affirm that besides being a garbage collector, Carolina was a revolutionary whose works deserve to be revealed!

Keywords: Memory, Slam, Women, Black, Poetry

\section{Resumen}

Una Sabiduría en Desesperación. Hay que Gritar a los Oídos de Aparente Sordera: Nosotras somos todas Carolina!

El objetivo en este ensayo es reanudar la poesía transformadora como fuente de inspiración y de negación frente a la realidad que enfrentan las mujeres negras en las regiones

Centro de Estudos Sociais, Universidade de Coimbra, 3000-995 Coimbra, Portugal.

Endereço Postal: Rua Velha, n. ${ }^{\circ} 5$ - 2. ${ }^{\circ}, 3000-406$, Coimbra, Portugal.

Endereço eletrónico: elainesantosabc@gmail.com

1 Cabe ressaltar que este artigo só existe devido à colaboração, apoio e fortalecimento das amigas de luta: Amy Montemor, Cláudia Cambraia, Elvira (CES), Josilane Lima e Lolo Arziki. Somos mulheres negras, oriundas da realidade periférica e onde quer que estejamos nunca poderemos negar nosso estatuto, SOMOS TODAS CAROLINA! Agradeço também ao Prof. Dr. Sinclair Guerra que gentilmente ofertou-me os livros de Carolina para redação deste artigo.

2 Colocar o texto na primeira pessoa do plural foi intencional, já que, enquanto mulher negra e periférica, faço parte de um projeto coletivo. Ainda que a escrita seja individual, cada uma de nós carrega uma parte de todas aquelas que lá permaneceram. 
periféricas. Con este fin enunciaremos Carolina María de Jesús, escritora negra que trabajaba como recolectora de basura en Brasil. Nuestro objetivo es evocar esta voz silenciada pero que gritaba. La metodología es la sintaxis sociológica de algunas obras de Carolina, con el fin de rescatar, para aquellos que de eso no son conscientes, la violencia que impregna la existencia de esta voz que sigue marginada. Afirmamos que Carolina no era una recolectora de basura, ella fue una revolucionaria que merece ser descubierta!

Palabras Clave: Memoria, favela, mujeres, mujeres negras, poesía

\section{Introdução}

Mulher e negra, Carolina Maria de Jesus nasceu em 1941 em Sacramento - no Estado de Minas Gerais, no Brasil - e mudou-se para São Paulo, para a favela do Canindé em 1947. Cursou apenas os estudos iniciais, facto que não a impediu de escrever e contaminar-se do vírus literário (Perpétua 2014). Produziu vasto material, obteve êxito no primeiro livro publicado, contudo, morreu como catadora, o lugar que socialmente lhe foi outorgado. Esta análise se faz em consonância com o contexto da mulher negra, que é atemporal, uma vez que há muitas «Carolinas» desvanecidas nas periferias brasileiras.

Através de seus escritos, Carolina nos mostra que o mundo não é um mero espetáculo. Sua forma de vida, manifestada na repetição missiva, desperta-nos à consciência de que há algo errado neste mundo. Sua escrita lança os leitores à inquietude, ao desconforto. Logo, nos permite sair do monólogo entre consciências isoladas, dispersas nesse pequeno mundo individual e individualista para pensar um projeto maior de insubmissão ao que nos aparece como um destino imposto. Tal como Carolina, que escreveu demasiadamente como maneira de desarvorar-se daquilo que lhe era apresentado como vida. Reuniu mais de 20 cadernos que originaram seu livro mais conhecido publicado em 1960, Quarto de Despejo: Diário de uma favelada.

15 de julho de 1955 - Aniversário de minha filha Vera Eunice. Eu pretendia comprar um par de sapatos para ela. Mas o custo dos gêneros alimentícios nos impede a realização dos nossos desejos. Atualmente somos escravos do custo de vida. Eu achei um par de sapatos no lixo, lavei e remendei para ela calçar [...].

18 de julho de 1955 - [...]. As mulheres saíram e deixou-me em paz por hoje. Elas já deram o espetaculo. A minha porta atualmente é theatro. Todas as crianças jogam pedras, mas os meus filhos são os bodes expiatórios. Elas alude que não sou casada. Mas eu sou mais feliz do que elas. Elas tem marido. Mas, são obrigadas a pedir esmolas. São sustentadas por instituições de caridade.

Os meus filhos não são sustentados com pão de igreja. Eu enfrento qualquer espécie de trabalho para mantê-los. E elas, tem que mendigar e ainda apanhar. Parece tambor. A noite enquanto elas pede socorro eu tranquilamente no meu barracão ouço valsas vienenses. Enquanto os esposos quebra as tabuas do barracão eu e meus filhos dormi- 
mos socegados. Não invejo as mulheres casadas da favela que levam vida de escravas indianas. Não casei e não estou descontente. Os que preferiu me eram soezes e as condições que eles me impunham eram horríveis.

[...]. Eu era revoltada, não acreditava em ninguém. Odiava os políticos e os patrões porque meu sonho era escrever e o pobre não pode ter ideal nobre. Eu sabia que ia angariar inimigos, porque ninguém estqa habituado a esse tipo de literatura. Seja o que Deus quiser. Eu escrevi a realidade. (Jesus s/d, 9, 14, 173)

Sua combatividade é inspiradora para o recorte que aqui se faz, à retomada da esperança, frente a uma realidade mundial ainda mais difícil para os pobres, principalmente para as mulheres negras - base da pirâmide social -, recuperaremos a vivacidade por meio da escrita. A compreensão de uma poesia transformadora, neste texto, se alicerça na formulação feita por Bastos (2012, 2), que, ao utilizar o aporte Lukacsiano, afirma que a arte é a aparência e a essência. Em contacto com a arte, somos levados a um processo catártico de reencontro com o cotidiano de modo a querer transformá-lo. $\mathrm{O}$ recetor da arte, em suas diversas formas de expressão, não é um ser vazio, é sempre levado a alguma mudança em sua essência, a partir dos desassossegos ante a obra exposta. Neste tocante, Bastos afirma

A arte supera a imediatez da vida cotidiana, colocando em seu lugar uma nova imediatez. A imediatez artística resulta, pois, de um conjunto complexo de mediações que, na vida cotidiana, o homem não pode perceber. Preso às aparências e à imediatez, o homem percebe as relações humanas como relações entre coisas. Este caráter fantasmagórico da perceção do homem inteiro é definidor do fetichismo da mercadoria.

[...]

Do ponto de vista de Lukács, a poesia tem um papel na história, que consiste em dar a ver a essência ocultada pelas aparências da imediatez da vida cotidiana. (Bastos $2012,2-3,6)$

Assim sendo, Carolina prorrompe as contradições da imediatez visível, ou seja, por meio de sua história, refletimos acerca da exclusão humana em sua inteireza. Este resgate é também um modo de fortalecer e abrilhantar nossos anseios, evocando uma mulher escritora, negra e lutadora. Partiremos da premissa de que as palavras cumprem um avultado papel e são extremamente ricas comparadas com as pobrezas e as limitações impostas pela vida. Assim, engendraremos a trama de vida da escritora em uma análise sociológica do período por ela vivido e, a partir da «Escrevivência», termo cunhado por Conceição Evaristo denotaremos a sintaxe deste ensaio. Ou seja, a leitura sociológica da exclusão como corpo, condição e experiência. Conceição Evaristo, ${ }^{3}$ fala do lugar ocupado pela escrita da mulher

Conceição Evaristo publicou pela primeira vez na Série Cadernos Negros que hoje é uma das páginas que concentra um grande número de escritores e escritoras da afro-literatura. Disponível em http://www.quilombhoje.com.br [consultado em 23.09.2016]. 
pobre e negra colocando-a como um «corpo» que vai à vida também por meio do registro (Oliveira 2009, 622-623). O lirismo trágico trazido pela subjetividade negra também é a leitura de si mesma, de sua condição no mundo. O universo das palavras passa a ser usado como um mecanismo para suportar a realidade, algo percebido na obra caroliniana. Logo, através da realidade e dos elementos sociais, alçaremos as raízes sociológicas que perpassam as obras de Carolina. Ressaltando o processo que a levou ao auge e à derrocada.

Seu primeiro livro, Quarto de Despejo, alcançou 70 mil exemplares em menos de 12 meses, provocando explosivo sucesso editorial (Machado 2006, 106). Traduzido em 13 idiomas, o fenómeno Carolina é pouco debatido no mundo académico (Santos 2009). Perpétua $(2014,23)$ afirma que o esquecimento da escritora ocorreu pelas mesmas razões que a fizeram emergir, ou seja, ela despontou numa época em que havia a necessidade política em construir um sujeito que retratasse as minorias sociais. Não um sujeito reconhecido, mas como massa de apoio aos chefes ${ }^{4}$ de Estado que, quase sempre, a desprezavam (Santos 2009, 85).

Traçando um paralelo com o grande lutador Mandela, Carolina - que escrevia a qualquer custo, muitas vezes sem ter o que comer - demonstra aquilo no qual ele também acreditara quando afirmava ser a educação o motor do desenvolvimento individual a partir do que construímos com aquilo que temos (Mandela 2009, 165). A nossa leitura do mundo transpõe este referencial. A educação para os pobres nunca alcançou o nível de transformação para a compreensão crítica do mundo. Porém, para ser uma escritora, basta escrever, escritor é aquele que escreve e não o que publica, contudo, como afirma Evaristo, a literatura canónica já tem seu espaço sacramentado ${ }^{5}$ daquilo que é considerado importante e interessante para os leitores. Neste sentido, a realidade vivida pela mulher negra não é alvo do fascínio literário, como aparece em Diário de Bitita - último livro de Carolina escrito antes de seu falecimento em 1977 -, os dramas daquela mulher ainda permanecem e passam desapercebidos (Santos 2009).

O homem pobre deveria gerar, nascer, crescer e viver sempre com paciência para suportar as filáucias dos donos do mundo. Porque só os homens ricos é que podiam dizer «Sabe com quem você está falando?» para mostrar superioridade. Se o filho do patrão espancasse o filho da cozinheira ela não devia reclamar para não perder o emprego. (Jesus 2007, 40)

Este texto, dividido em duas partes, contextualizará o drama de vida e as dubiedades da autora na emergência de sua corajosa escrita e suas formas de

Grifo do autor.

Pensamento abordado no Encontro com Conceição Evaristo realizado na UEMG (Universidade Estadual de Minas Gerais), em 4 novembro de 2015, quando falou sobre seu livro Olhos d'água, uma das obras literárias que foi indicada como leitura obrigatória no Vestibular de 2016. Disponível em https://www.youtube.com/watch?v=n0YupSAbJ-k [consultado em 23.09.2016]. 
transgressão à realidade. Partindo da invisibilidade para a visibilidade das mulheres negras, como um convite sensível aos seus escritos e a reflexão sobre a construção dos estereótipos.

\section{O cenário da coragem}

Carolina foi a primeira escritora negra no Brasil dos anos 1960, momento em que a literatura ainda era inacessível para as mulheres de um modo geral. Emergiu num período de reivindicações das minorias brasileiras aliadas à busca por uma identidade nacional num modelo económico (Perpétua 2014, 23). Itinerário utópico que está registrado:

Chorei pensando na quantidade de roupas que eu lavava e passava. Cuidar do quintal, olhar a casa quando ela estava ausente. Não roubava. Cuidava de tudo como se fosse meu. Decidi procurar outro emprego. Ou deixar o interior. Pretendia encontrar um trabalho com melhor remuneração. Eu tinha que aprender a reagir, a exigir respeito nos contratos de trabalho. Mas não tinha casa e já estava cansando da minha vida andarilha. A patroa era estrangeira, e eu nacional. Eu não podia competir com ela. Ela era rica, e eu pobre. Ela podia mandar prender-me. Continuei trabalhando.

A patroa sorria e dizia que tinha encontrado uma idiota que trabalhava quase de graça. Depois do jantar eu saía andando pela cidade, procurando emprego. Eu estava sã. Não havia obstáculo para vedar-me. Indicaram-me uma professora que estava procurando uma criada para vir para São Paulo. Fui procurá-la, ela aceitou-me. Que alegria! Voltei correndo, fui preparar as minhas roupas. Não avisei a patroa que ia sair, ela já havia me despedido.

Até que enfim, eu ia conhecer a ínclita cidade de São Paulo! Eu trabalhava cantando, porque todas as pessoas que vão residir na capital do estado de São Paulo rejubilam como se fossem para o céu.

Quando cheguei à capital, gostei da cidade porque São Paulo é o eixo do Brasil. É a espinha dorsal do nosso país. Quantos políticos! Que cidade progressista. São Paulo deve ser o figurino para que este país se transforme num bom Brasil para os brasileiros. (Jesus 2007, 202-203)

$\mathrm{Na}$ época, a afro-literatura que circulava nos jornais paulistanos restringia-se ao cotidiano político e militante deste grupo étnico, a presença da cultura negra em São Paulo possuía pujança (Silva 2008, 58-65). Contudo, nas lutas encampadas no pós-escravidão inexistia um ajuntamento negro suficientemente forte que permitisse uma melhor articulação entre os vários grupos e suas raízes nos diferentes estados brasileiros. Além disto, o facto de São Paulo constituir-se numa ascendente economia industrial cosmopolita colocava-os num patamar de negros elitistas, que, letrados, disputavam espaços com os brancos, concebendo a cultura escrita sempre como um bem valorativo (Silva 2008, 70-72). 


\section{Imagem 1}

Um dia apoderou-se de mim um desejo de escrever: Escrevi. (Jesus 1994, 185)

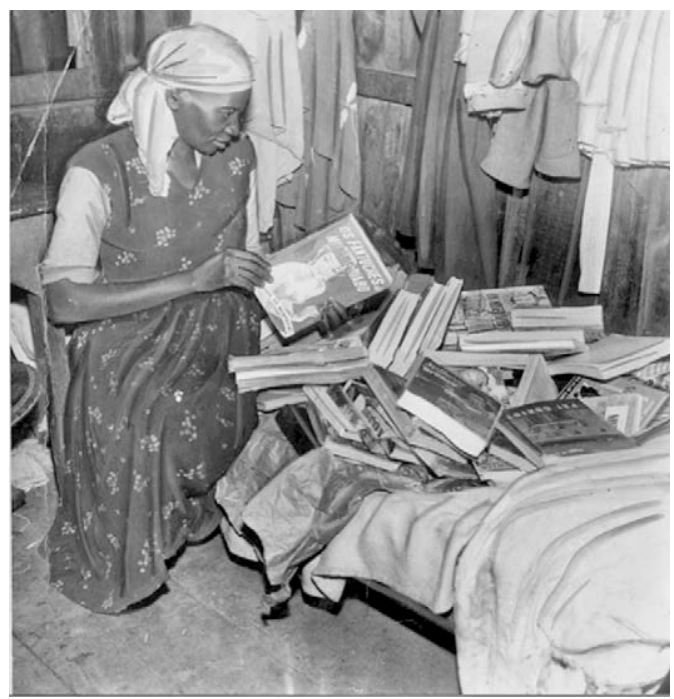

Fonte: A imagem pertence ao jornal Última Hora, retirada do acervo digital da escritora.

Disponível em www.vidaporescrito.com [Consultado em 22.07.2016].

Para Florestan Fernandes (1978), na década de 1960 existia uma elite negra num Brasil remanescente da escravidão, composta por migrantes urbanos que, mesmo trabalhando em empregos modestos, possuíam uma ocupação melhor do que o negro da lavoura. A questão identitária é fundante neste sentido, não se pode pensar o negro do campo igualmente ao negro citadino, a discriminação atua dentro dos contextos onde o negro se insere, ela é estrutural (Fernandes 1978). Na época de Carolina, os negros não fugiam à regra, envolviam-se em atividades comunitárias ${ }^{6}$ adquirindo um sentido político da vida cotidiana, pormenorizada nos dilemas da comunidade, alçando assim uma identidade urbana (Silva 1990, 74-88). Contudo não podemos omitir que, apesar desta organização comunitária, as(os) negras(os) paulistanas(os) se inseriram em um todo urbanizador que as(os) colocava à margem, isto é, viviam nas periferias onde a repressão policial era mais visível e eram excluídos dos espaços públicos e decisórios (Silva 1990). Da década de 1960 até aos dias atuais, a comunidade periférica em São Paulo permanece ocupando terrenos como mecanismo de garantir uma moradia quiçá legitimada pelo Estado.

São estes os negros e negras que migraram para São Paulo no início da industrialização/urbanização. As culturas estavam em constante transformação. Como

O autor menciona a formação de um policiamento repressivo característico da vigilância da comunidade negra, a chamada «Polícia de Costumes», que prendia todas as pessoas que praticavam ações consideradas como feitiçaria, rebaixadas por ter origem africana (Silva 1990, 80). 
mencionado, mesmo entre os negros havia uma estratificação e é neste ponto que classe e etnia se cruzam. As especificidades são também generalidades, tratamos de uma mulher pobre e negra num contexto urbano, que, sabendo-se segregada, possuía dentro de si o quilate da comunicação. Porém, ao examinarmos a situação das mulheres negras no Brasil, encontraremos muitas «Carolinas» em contextos diversos. Ressalvadas as dissemelhanças das frações existentes dentro de uma classe, suas desigualdades se cruzam, são consubstanciais no que tange a discriminação, abandono e desprovimento das disposições necessárias para edificação de uma história. Carolina foi exemplo disto, pois o sucesso do seu livro a aproximou dos escritores negros conhecidos, porém, apesar da pertença racial epidérmica, sua afirmação na militância política organizada nunca aconteceu. ${ }^{7}$

Para ter seus escritos publicados Carolina acatou, por intermédio de Audálio Dantas, o lançamento de Quarto de Despejo. O editor remontou os textos em ordem cronológica, trazendo um ponto de vista estratégico para a divulgação, algo que não era então pensado pela autora (Perpétua 2003, 63-64). Reorganizando seus escritos, o editor construiu uma imagem caricaturesca de uma mulher forte e passiva, e até preconceituosa, como não poderia deixar de ser. «Eu vi, eu senti. Ninguém podia melhor do que a negra Carolina escrever histórias tão negras. Nem escritor transfigurador poderia arrancar tanta beleza triste daquela miséria toda. Nem repórter de exatidão poderia retratar tudo aquilo no seco escrever» (Dantas 1960, 10).

Audálio Dantas organizou-os de modo a ocultar aquilo que aparentasse erudição, elevando uma escrita popular que se enquadrasse no imaginário estereotipado acerca dos favelados. O texto sofreu supressões até no que tange às reflexões sobre a vida, suas observações de humor, tristeza, sonhos que fugiam às generalizações do pobre (Perpétua 2003).

No estudo da transposição da escrita cursiva para a letra de fôrma, o exame do processo de substituição evidencia a intenção do editor de compor uma imagem da autora diferente da que aparece no manuscrito. Nesse tipo de interferência, nota-se que o editor elimina o que possa haver de suposta erudição ou mesmo de escorreito na linguagem de Carolina quando substitui suas supressões por termos mais populares [...]. Também foi suprimida a maior parte das observações que apontam o posicionamento político de Carolina e que acompanham seus comentários sobre os acontecimentos locais, nacionais e internacionais. Some-se a essas supressões a manutenção, na publicação, de registros carregados de expressões preconceituosas e agressivas de Carolina em relação a seus vizinhos da favela e teremos, a partir dessa editoração, uma idéia incompleta e pouco lúcida de sua percepção sobre o mundo em que vive. (Perpétua 2003, 63-65)

Neste ponto há divergências nos estudos pois alguns apontam que a partir das cartas não publicadas é possível perceber uma postura política mais incisiva de Carolina, diferentemente do que fora demonstrado no seu livro mais famoso. De todo modo, Carolina não era organizada politicamente de forma partidária, ela era uma militante da vida. 
Omitindo enormes trechos, Audálio Dantas usou a justificativa de que Carolina era deveras repetitiva e possuía uma ânsia descritiva que a atrapalhava (Perpétua 2003). O editor despolitizou-a e tornou depreciativos os relatos de Carolina acerca dos vizinhos favelados, facto que favoreceu o ódio à escritora por parte dos vizinhos. Estes se sentiam usados, viam-na como uma impostora. A história de Carolina foi subtraída para que sua obra aparecesse como um produto do desenvolvimentismo. Seu período áureo explanou-se nas contrariedades que perpassam os sujeitos destituídos de acessos mínimos, ou seja, a escritora foi sublevada à condição de literária, todavia, reduzida a retratar somente o interesse do momento histórico, isto é, a fome e a pobreza. A escritora mostrou-se descontente e, quando de seu descenso em sua casa de tijolos, Carolina escreveu:

Vou abandonar a literatura. Com as confusões que enfrento com o quarto de despejo, fui perdendo o amor pela literatura. [...] saímos da livraria eu fui quêixando que vou deixar a literatura de lado. Vou arranjar um emprego. Não me adapto a ser teleguiada. Com o dinheiro que recebo da Europa eu queria dar entrada noutra casa e alugar a que estou morando. Com o aluguel eu ia pagando as prestações da casa. Mas o dr. Lélio e o Audálio interferiram - querem pagar a casa de uma vez e atrapalha os meus progetos. Avisei ao senhor Bertini, se eu não tiver dinheiro para comprar comida para os meus filhos eu não vou a Argentina Ele ouviu-me desinteressado. Pensei: ele ainda não me conhece. Não sabe que eu sou descendente da bomba atômica. (Jesus 1996a, 136-137)

Vivia-se um período de ausência de debates em relação à formação do sujeito periférico, sobre o significado e as implicações do nascer e viver na «periferia, favela». Desta forma, a negação daquele espaço social como forma de torná-lo invisível fez da periferia local à margem do potencial humano que pudesse ali ser desenvolvido. Este espaço reduziu-se ao lugar para gente pobre, suja e incapaz; e não como um território impreciso, salvaguardado na não consolidação do ponto de vista urbanístico e de uma lógica ideológica higienista (Domingues 1996, 9-12).

Nós somos pobres, viemos para as margens do rio. As margens do rio são os lugares do lixo e dos marginais. Gente da favela é considerado marginais. Não mais se vê os corvos voando as margens dos rios, perto dos lixos. Os homens desempregados substituíram os corvos. (Jesus s/d, 48)

Nesta toada, Carolina aparecia com um ar de celebridade marginal, todos queriam conhecer a favelada que escrevia, ${ }^{8}$ num tom exótico e romantizador da desigualdade. Obviamente que a conveniência deste discurso subsiste nas periferias, implícita às lógicas de poder que são hierarquizadas e estruturais. Na segunda

8 Grifo nosso. 
parte do texto falaremos do que foi a nossa Carolina no quadro sessentista, quando o povo acreditava que as políticas getulistas seriam o seu farol, Carolina afirmava

Meu irmão queria fardar-se. Mas o homem que não lutasse não era homem. Lutando para o Getúlio, é como se estivesse depositando dinheiro num banco. E os juros vão ser o bem-estar do nosso povo. Quem estava fazendo aquela revolução eram os ricos. Mas eles se revoltaram, por que? Quem deveria e deve revoltar-se somos nós que somos os pobres, que trabalhamos sem melhorar nossa condição de vida, ganhamos apenas as unidades que não cobrem nossas necessidades. Temos que ficar semianalfabetos porque o curso superior está ao alcance somente dos poderosos. (Jesus 2007, 196)

Em outro trecho, afirmou Getúlio, o presidente no período, como o pai dos pobres: ${ }^{9}$

Foi orgulho de nossa gente,

É opinião brasileira,

Que tivemos um presidente,

Que honrou nóssa bandeira

[...]

Retirou o operário a tibieza,

Deu-lhe apoio e proteção,

Convidou com delicadeza,

A colaborar no progresso da nação.

(Jesus 1996b, 135)

Esta era a sinopse da política simbólica, uma abordagem angular da realidade que não permitia enxergar a essência dos problemas da exclusão. Uma manipulação dramatizada, onde o que importa é o «efeito visível» através dos meios de comunicação e não uma preocupação verdadeira na resolução dos problemas sociais (Souza 2006, 149).

\section{Nossa Carolina}

Ao tratar de uma escritora do porte de Carolina afastamo-nos da premissa culturalista, sobrelevada por alguns grandes nomes ${ }^{10}$ que realizaram estudos sobre a comunidade negra no Brasil. Este é o eixo axiomático desta secção, elaborar o por que foi - e ainda é - esta mesma folclorização que leva a exacerbar

Grifo nosso.

10 Trata-se de Franz Boas, Gilberto Freyre e Edison Carneiro, que contribuíram para uma análise cultural de grupos sociais, mas que, ao separar a cultura da política, deixaram flancos para teorias reducionistas e biologizantes. 
apenas o aspeto cultural das/os negras/os, escamoteando a discriminação, através da falácia da democracia racial (Souza 2009). No debate realizado por Silva (2008), demonstra-se que a literatura negra no Brasil partia da inconformidade em relação à realidade posta, uma tentativa de dar aos negros alteridade ressignificando aquilo que era difundido e que os associava ao negativo. Segundo Silva,

[Carolina] fez sua aparição inesperada [em um período em que] a literatura se apresentava politicamente como um espaço privilegiado de elaboração da identidade negra. Em torno do conceito de negritude, ${ }^{11}$ consolidavam-se propostas estético-políticas que postulavam pela radical inversão das representações negativas elaboradas sobre o negro.

[...]

Mesmo quando estes indivíduos conseguiam publicar suas obras em espaços mais amplos, cumpriam geralmente um estágio nos pequenos jornais negros. (Silva 2008, 63-64, 69)

Recém-chegada em São Paulo, atraída pelo impulso da industrialização e o sonho de uma vida melhor, afastava-se dos poucos escritores negros do período, uma elite negra ${ }^{12}$ intelectual em ascensão. A obra caroliniana se desenvolvia em paralelo àqueles que poderiam ser seus companheiros no ativismo. Estes lutavam por mais acessos, organizavam saraus em diferentes associações e neste ponto a autora era uma outsider, não era completamente organizada politicamente e ao mesmo tempo sua escrita não comportava o considerado «culto» pela literatura hegemónica. Ela não seguia a norma culta também assimilada e incorporada pelos escritores negros e militantes. Segundo Santos $(2009,18)$, ao ler Carolina e desprender-se do critério literário elitista, viu que a norma culta só pode transmitir conteúdo culto e sua narrativa não era a oficial, era real. A nosso ver seu brilhantismo está nisto, nunca chegaríamos à essência desta mulher estilhaçada socialmente, mas humanamente sensível à poesia do real, sem sua obra. Ela detém uma voz que não localizamos na sociedade, o vocabulário de Carolina é ausente nas lutas, ela não fala da privatização, da questão agrária, ao contrário, ela é a luta, na esfera mais múltipla, no seu complexo de complexos. A voz dos marginalizados, recém-chegados a São Paulo, uma revolucionária, pois as condições de sua escrita eram impossibilitadas no sentido material e humano, mas ela o saltou, dentro de si.

11 Negritude é um conceito polissémico cunhado pelo poeta antilhano, radicado em França, Aimé Césaire. As ideias centrais reúnem a «reversão do negativo da palavra negro para dela extrair um sentido positivo» (Césaire in Silva 2008, 64). Envolve também a rejeição da assimilação cultural do mundo branco.

Cabe «enegrecer» neste ponto que a chamada «elite negra» ficou conhecida no centro urbano por seu papel intelectual e não propriamente por sua condição económica. Em suma, não eram os possuidores dos meios de produção. 
Quando eu fiz o meu barracão era um Domingo. Tinha tantos homens e nenhum auxiliou-me sobrou uma tabua de quarenta centímetro de largura era em cima dessa tabua sem colchão que eu dórmia.

Sempre fui muito tolerante pensava melhores dias há de vir se Deus quizer comecei preparar o enxoval do meu João José. Fazia tratamento pre Natal no Hóspital das Clinicas. Eu sentia tonteiras e caia mêia inconsciente. Alguns passava-me e não me olhava. Outros fitava-me e dizia.

- Negra nova podia e pode trabalhar mas prefere embriagar-se.

Mal sabiam êles que eu não me sentia bem alimentação deficiente, aborrecimentos moraes, e físicós. Quando eu me sentia em condições de aguentar-me de pé levantava e prosseguia. As vêzes eu ia na Igreja imaculada pedir pão. Quantas vezes a criança debatia no meu ventre. Quando eu chegava no meu missero barraco dêitava.

Os visinhos murmurava. Ela é sosinha deve ser alguma vagabunda. É crença generalisada que as pretas do Brasil são vagabundas. Mas eu nunca impressionei-me com o que pensam ao meu respeito. Quando os engraçadinhos quiseram dizer-me gracólas, eu disse:

- Eu sou poetisa. Peço respeitar-me mais um pouco. (Jesus 2014, 42-43)

Suprimida de forma literária, Carolina registrava o cotidiano do pobre que busca sentido nas minudências da vida. A narradora adaptada, recebeu voz nos moldes permitidos, saciando a curiosidade dos entediados. Naquele período a favela era compreendida como local transitório, local de migrantes e trabalhadores que se adaptariam ao progresso do país (Meihy e Levine 1994, 124). Seu «tutor iluminista» fez o que cabia numa sociedade dos padrões; encontrou na sujidade da favela uma escritora que oferecia a pobreza vendável, «uma mercadoria que estava na onda da discussão política, social e diretamente ligada ao desenvolvimento urbano nacional» (Meihy e Levine 1994, 125).

E assim a pobreza chegou ao conhecimento público. Por meio de um conceito caricaturado e bastante difundido - principalmente pela classe média, que por possuir valores altamentes permeáveis, ora alinham-se a uma visão transformadora, ora reproduzem um discurso conservador. Esse grupo que nem classe é, fantasia uma realidade descompassada, bem como as necessidades das pessoas. São, por vezes, generosos, usualmente pouco críticos, não alcançam a essência dos problemas, não inferem a realidade como constructo do cotidiano. Toda esta construção social está pautada e legitimada no esquecimento de uma grande parcela da sociedade, entretanto é tarefa social/individual desvelar o cotidiano funesto dos despossuídos, daqueles que nasceram sem os louros, virtudes e regalias da socialização num ambiente saudável.

Desconsiderando as clivagens da pobreza, que ultrapassam os limites da sobrevivência material, o pobre do imaginário social construído no Brasil «é aquele esquálido e fotográfico, que existe em muitos lugares do mundo» e que é insolentemente retirado da participação no que tange os destinos da sociedade (Martins 2000, 274). O essencial da pobreza moderna capitalista, não está na falta 
de condição material e, sim, na transformação do ser humano em mercadoria, isto é, na sua desumanização.

Diante este abismo, Carolina é possuidora da criatividade popular que perturba a lógica dominante e não obteve o devido reconhecimento (Guimarães 2014, 78). Por outro lado, não alcançamos a lucidez obtida por Carolina, não é fácil desenredar-se de todos os métodos insidiosos que nos tornam míopes. Nossa autora queria ser ela mesma, promotora da sua vida, em sua forma, em sua cor que ela exaltava:

Quantas coisas eu quiz fazer

Fui tolhida pelo preconceito

Se eu extinguir quero renascer

Num país que predomina o preto.

(Jesus 2007, 33)

Foi a inversão dos valores postos, sua fala e escrita são a do humanismo que não se dobra diante a magnitude do mal-estar vivido.

A venda dos livros permitiu a Carolina comprar uma casa feita com tijolos, onde foi morar com os filhos até 1964, seu descenso acompanha o período do fim do populismo, quando já não era mais necessária como representação viva da pobreza (Vogt 1983). Em 1966, após seus anos dourados, ela foi vista na rua maltrapilha, exercendo a ocupação de catadora tangenciada pela pobreza e pela fome. Segundo Vogt, Carolina «morreu como sempre viveu: pobre» (1983, 208).

Ser pobre e negro no Brasil é uma violência avassaladora em termos materiais, mas é também uma violência simbólica invisibilizada, naturalizada e até despercebida (Sousa 2009). Atualmente vigoram as novas formas de continuidade desta violência, mais modernas, mudaram as armas e os instrumentos de violência, já não utilizam o chicote do senhor mas, sim, um prolongamento do passado. Uma vez que não tivemos projetos nacionais continuados, nosso constructo se deu por meio da «colonização patológica» de todas as esferas da vida pelo dinheiro, entre nós implica uma pobreza de debate público, uma pobreza humana de qualquer empatia e reconhecimento ao outro (Sousa 2009, 9). A escritora figurou por meio da estética, do exotismo, ${ }^{13}$ daquela que subsiste humanamente trespassada pelo discurso meritocrático da mulher que com fome escrevia. Carolina possuía uma consciência adiantada para um mundo retrógrado, nunca terminaremos de explorá-la. Ela resgatava a sabedoria de uma vida que poderia ser outra, tinha pensamentos confortáveis para aguentar a dureza da vida, mas nunca deixou de confrontar o real.

13 Cabe ressaltar que no lançamento de seu primeiro livro Quarto de Despejo estava presente uma multidão inclusive o então ministro do trabalho do governo de JK (Juscelino Kubitchek) - João Batista Ramos - que prometeu uma casa a Carolina, não deu. Disponível em http://www.comciencia.br/reportagens/violencia/vio12.htm [consultado em 20.07.2016]. 


\section{Conclusão}

Parece determinante trazer à tona os quesitos que levam os indivíduos ao fracasso ou ao sucesso e que é ocultado por meio de ideologias e discursos consensuais. Nos parece pujante buscar a medula das problemáticas sociais, nomeando os dilemas que perpetuam a existência de classes privilegiadas e classes excluídas. Assim sendo, as alterações não se fazem somente de uma visão economicista liberal mesquinha de distribuição de renda, vulgo, migalhas, para a população, como se pensava possível na década de 1960. Nossa modernização conservadora é retratada por meio da obra de Carolina na dicotómica história da inclusão excludente. Perpétua (2014) menciona que muitos trechos do «Diário Caroliniano» foram incorporados aos discursos das autoridades da época, como palavras que simbolizavam a transformação no devir. E a pobreza foi utilizada pelo cinismo da manutenção hierárquica. No Brasil, a história se repete sempre como tragédia, vivemos neste abismo.

Neste ínterim, Carolina representa a fuga para frente, uma tentativa de escapar do ciclo da pobreza desdita, libertando-se da esperança sem sair dela. Viveu sem esperar nada, não tinha mais nada a perder, habitou - se de forma axial aquilo que a embrutecia e transformou-se. $\mathrm{O}$ mundo, para aqueles considerados incompetentes, é assim, para pegar ou largar, renuncia-se a felicidade - nos ditames impostos - para viver no limite do possível (Comte-Sponville 2015). Resistir ao desespero só é possível quando estamos na vida tal como ela é, sem o sentimento de autoindulgência. Carolina é, para nós, um ícone de luta, de galhardia, que não se curvou frente ao racismo e à miséria, seus escritos permanecem e resvalam na história de muitas mulheres negras.

E é nas nossas circunstantes que nos (re)encontramos com a realidade, nas memórias esquematizadas pelo senso comum, onde a exacerbação dos conflitos e a conscientização são sempre tarefas custosas, que demandam uma vitalidade que Carolina nos deixou. E como percebemos, em seu retrospecto, nem sempre nossa luta será exitosa, encarar a verdade da realidade exige coragem. A coragem de rememorar os bilhetes deixados na geladeira (que era azul e quebrada, tinha uma madeira a prender a porta para não cair), tais bilhetes eram a expressão de carinho e comunicação de um pai que não conseguia acompanhar o crescer dos filhos, devido à quantidade de horas no trabalho. A pouca comida que tínhamos, por vezes, somente o fubá brasileiro que misturado à água rendia e era dividido entre os irmãos para que ninguém passasse fome. As roupas de cama vendidas por ambulantes, também moradores da favela, eram pagas através de prestações mensais, se tornavam o luxo anual necessário para nos sentirmos «gente limpa». Os cursos de maquiagem e manicure oferecidos pela Prefeitura da Cidade como única possibilidade de ganhar algum dinheiro, quiçá uma ascensão social, esta era a formação que «gratuitamente» nos foi oferecida. A mudança para uma cidade grande, «A Capital», representada no nosso imaginário por aquilo que víamos na televisão, apresentado como um sonho que nunca fora alcançado. A vida e o seu adoecer que nos obriga a cuidar uns dos outros, como irmãos e irmãs de luta em um destino histórico. Sendo assim, suspei- 
temos do discurso legitimador, pois nascemos sob a mesma égide disciplinadora e moldada para atender determinados imperativos. Carolina nos trouxe a necessidade da sofisticação da variável racial no que tange a desigualdade brasileira, ela gritou e talvez seja esta a única saída deste diálogo entre surdos que vivemos. Neste sentido, não há um método, não somos todos objetos de estudos, nosso atilho é social e humano e é deste encontro empático que nos fazemos autónomos.

\section{Imagem 2}

Carolina presente

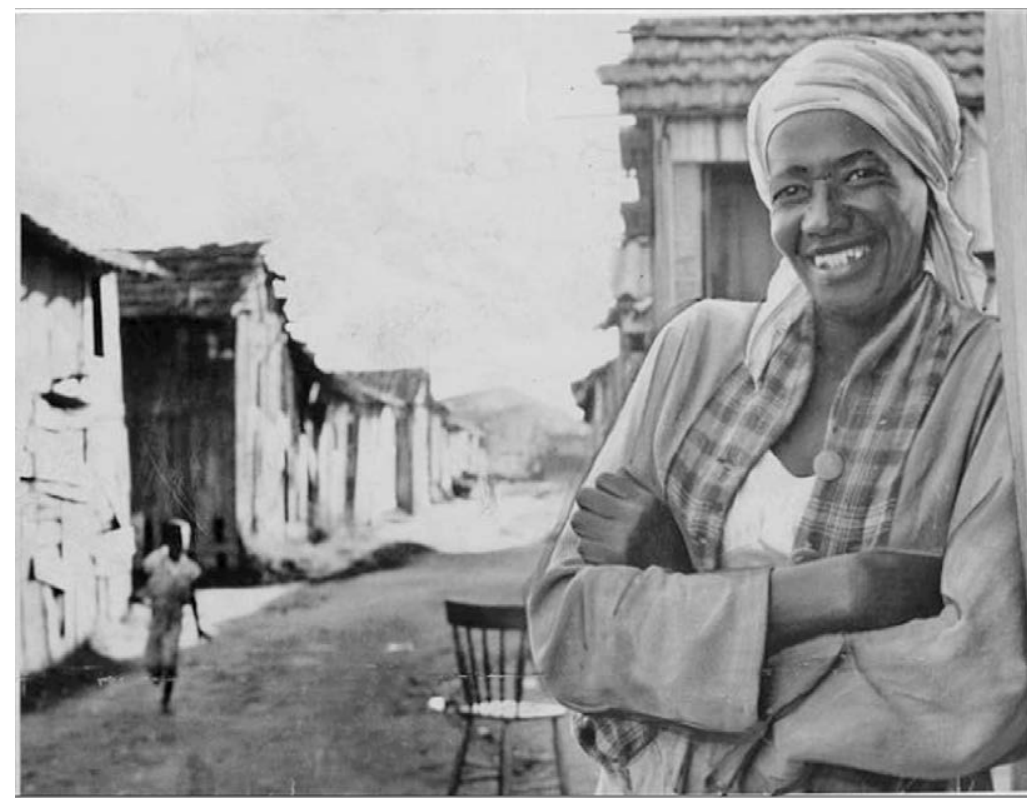

A imagem pertence ao jornal Última Hora, retirada do acervo digital da escritora.

Disponível em www.vidaporescrito.com [consultado em 22.07.2016].

\section{Referências bibliográficas}

Bastos, Hermenegildo. 2012. «Arte e vida cotidiana: a catarse como caminho para a desfetichização». Comunicação apresentada no VI Coloquio Internacional «Teoría Critica y Marxismo Occidental», Jornadas Internaciones «Actualidad de la Teoría Crítica», Facultad de Psicología, Universidad de Rosario, 11, 12 e 13 de outubro. Disponível em http://www.herramienta.com.ar/coloquios-y-seminarios/arte-e-vida-cotidiana-catarse-como-caminho-para-desfetichizacao

Comte-Sponville, André. 2015. A Felicidade, Desesperadamente (2. ${ }^{a}$ ed.). São Paulo: Martins Fontes.

Dantas, Audálio. 1960. «Nossa Irmã Carolina». In Quarto de Despejo: Diário de uma favelada, Carolina Maria de Jesus, 5-12. Rio de Janeiro: Francisco Alves. 
Domingues, Álvaro. 1996. «Sub(úrbios) e (Sub)urbano - o mal-estar da periferia ou a mitificação dos conceitos». Comunicação apresentada no III Congresso Português de Sociologia, fevereiro, Lisboa.

Fernandes, Florestan. 1978. A integração do negro na sociedade de classes. São Paulo: Ática.

Guimarães, Geni, F. 2014. «Até onde Carolina nos leva com seu pensamento? Ao poder». In Onde estaes felicidade?, organizado por Dinha e Rafaella Fernandez, 77-86 São Paulo: Me Parió Revolução. Disponível em http://www.letraria.net/site/wp-content/ uploads/2016/01/Onde-estaes-Felicidade-e-book-Letraria.pdf

Jesus, Carolina Maria. s/d. Quarto de despejo: Diário de uma favelada. São Paulo: Edição Popular. Jesus, Carolina Maria. 1996a. Meu estranho diário. São Paulo: Xamã.

Jesus, Carolina Maria. 1996b. Antologia Pessoal. Rio de Janeiro: UFRJ.

Jesus, Carolina Maria. 1994. Minha Vida. In Cinderela negra: a saga de Carolina Maria de Jesus: 172-189. Organizado por Meihy, José C. S. B., e Robert, M. Levine. Rio de Janeiro: UFRJ

Jesus, Carolina Maria. 2007. Diário de Bitita (2. ${ }^{a}$ ed.). Organizado por Carlos Alberto Cerchi e Alessando Abdala. Sacramento, Minas Gerais: Editora Bertolucci.

Jesus, Carolina Maria. 2014. Onde estaes felicidade? São Paulo: Me Parió Revolução. Disponível em http://www.letraria.net/site/wp-content/uploads/2016/01/Onde-estaes-Felicidade-e-book-Letraria.pdf

Machado, Marília Novais da Mata. 2006. «Os escritos de Carolina Maria de Jesus: Determinações e imaginário». Psicologia e Sociedade 18(2): 105-110. DOI: https://doi.org/10.1590/ S0102-71822006000200014.

Mandela, Nelson. 2009. Autobiografia de Nelson Mandela - Um longo caminho para a liberdade. Lisboa: Planeta.

Martins, José de S. 2000. «As mudanças nas relações entre a sociedade e o Estado e a tendência à anomia nos movimentos sociais e nas organizações populares». Revista Estudos Avançados 14(38): 268-278. DOI: https://doi.org/10.1590/S0103-40142000000100015

Meihy, José C. S. B., e Robert, M. Levine, 1994. Cinderela negra: a saga de Carolina Maria de Jesus. Rio de Janeiro: UFRJ.

Oliveira, Luiz Henrique Silva. 2009. «\$Escrevivênciał em Becos da memória, de Conceição Evaristo». Revista Estudos Feministas 17(2): 621-623. DOI: https://doi.org/10.1590/ S0104-026X2009000200019

Perpétua, Elzira D. 2003. «Aquém do Quarto de despejo: A palavra de Carolina Maria de Jesus nos manuscritos de seu diário». Estudos de Literatura Brasileira Contemporânea 22: 63-83. Disponível em http://periodicos.unb.br/index.php/estudos/article/view/2182 [consultado em 20.07.2016].

Perpétua, Elzira D. 2014. A vida escrita de Carolina Maria de Jesus. Belo Horizonte, Minas Gerais: Nandyala.

Santos, Joel Rufino. 2009. Carolina Maria de Jesus, uma escritora improvável (2.. ed.). Rio de Janeiro: Garamond.

Silva, José Carlos G. 1990. «Os suburbanos e a outra face da cidade. Negros em São Paulo, cotidiano, lazer e cidadania (1900-1930)». Dissertação de Mestrado em Ciências Sociais, Instituto de Filosofia e Ciências Humanas, Universidade Estadual de Campinas.

Silva, José Carlos G. 2008. «Carolina Maria de Jesus e os discursos da negritude: Literatura afro-brasileira, jornais negros e vozes marginalizadas.» História \& Perspectivas 39: 59-88. Disponível em http://www.seer.ufu.br/index.php/historiaperspectivas/article/ viewFile/19189/10327 [consultado em 19.07.2016].

Souza, Jessé. 2006. A invisibilidade da desigualdade Brasileira. Belo Horizonte: UFMG.

Souza, Jessé. 2009. A Ralé Brasileira: Quem é e como vive. Belo Horizonte: UFMG. 
Vogt, Carlos. 1983. «Trabalho, pobreza e trabalho intelectual (O quarto de despejo de Carolina Maria de Jesus)». In Os Pobres na Literatura Brasileira, organizado por Roberto Schwarz, 205-213. São Paulo: Brasiliense.

Elaine Santos. Elaine Santos. Socióloga, Licenciada em Geografia, Mestre em Energia na Universidade Federal do ABC (São Paulo) e Doutoranda em Sociologia no Centro de Estudos Sociais, Universidade de Coimbra (Portugal). Professora de Sociologia da Rede Estadual de São Paulo, organiza um Blog PAIDÉIA EDUCAÇÃO que tem como missão tornar os assuntos debatidos na Academia mais acessíveis aos alunos das escolas públicas. É também colaboradora do BLOGUEIRAS NEGRAS.

Artigo recebido a 02 de agosto de 2016 e aceite para publicação a 28 de novembro de 2016. 